Annals of Glaciology $5 \quad 1984$

(c) International Glaciological Society

\title{
OBSERVING POLAR-ICE VARIABILITY
}

by

\author{
H. Jay Zwally \\ (Goddard Laboratory for Atmospheric Sciences, NASA/Goddard Space Flight Center \\ Greenbelt, Maryland 20771, U.S.A.)
}

\section{ABST RACT}

The repetitive synoptic ice data obtainable by satellite sensing provide a means of studying the time-dependent behavior of both sea ice and ice sheets on climatic time scales. Examples of seaice parameters which may be measured are extent, concentration, and multiyear fraction; and examples of ice-sheet/ice-shelf parameters are surface elevation, ice-front position, extent and duration of summer melting, and ice accumulation rates. Desired snow-cover parameters include extent and snow depth or water-equivalent depth. The unique ability of satellites to measure such ice parameters and the characteristics of the consequent data sets significantly influence the structure of ice models that can be successfully used with the data. Ice data sets recently acquired by satellite sensing are described. The past decade of sea-ice data provides a detailed description of the interannual variability of sea ice on a regional and seasonal basis. Because of the longer time scales involved in ice-sheet variations, a comparable record of ongoing ice-sheet variations has not yet been established, but important baseline data sets are being developed.

\section{INT RODUCTION}

Sea-ice concentration has already been successfully used as a primary variable in certain sea-ice models for input and verification (Parkinson and Washington 1979, Hibler and Ackley 1982), whereas sea-ice thickness is a primary variable in other models (e.g. Coon 1980) that have been limited by a lack of suitable data. The small but potentiallyobservable changes in ice-sheet elevation will also require models specifically designed to study these changes. Traditionally, after ice models are constructed, data requirements have been considered by remotesensing specialists. However, the physics of the emission and propagation of electromagnetic radiation and the available technology combine to dictate the observable parameters with very little flexibility. Fortunately, these factors have united in recent years to begin to yield significant information about ice variability on a global scale, and from daily to decadal time scales. Because ice models are inherently more flexible than sources of long-term data, models need to be adapted or developed to complement the few parameters that can be obtained only from satellite remote sensing.

Determination of the variability of polar ice over climatically relevant time scales requires repetitive synoptic data on all high-latitude regions. Satellite data provide information on present $\mathrm{clim-}$ atic conditions in polar regions as well as information useful in studies of the time-dependent behavior of sea ice, ice sheets, ice shelves, and continental snow cover. Significant progress has been made in recent years on the observation of snow and ice during all weathers and in all seasons by passive microwave imaging, in particular. The seasonal cycle of sea-ice extent is now comprehensively described on a regional and hemispheric basis. Observations of ice-sheet surface $\mathrm{climate}$ parameters and changes in surface elevation have been initiated, as have satellite observations of changes in ice-shelf fronts. Recently, Matson and Wiesnet (1981) and Dewey and Heim (1982) described visual satellite observations of snow cover in the northern hemisphere since 1966. Advances have also been made in the microwave observation of the seasonal cycle of continental snow cover (Kunzi and others 1982). This paper provides an overview of some recent results of observing the variability of polar ice, specifically sea ice, ice sheets, and ice shelves.

\section{SEA-ICE VARIABILITY}

The primary variation of sea ice is the seasonal cycle, and the interannual variations of the seasonal cycle are of particular climatic interest. The interannual variability of sea ice includes significant year-to-year variations, short-term variations (over several years), and possible long-term trends (extending over a decade and longer). Primary variables describing the sea-ice cover are geographical extent, concentration or actual ice area, and the amount of multiyear ice pack. Other parameters such as sea-ice thickness and drift velocities are important for studies of ice dynamics and ice processes, but here we concentrate on parameters that can be obtained over the required spatial and temporal scales for climate studies.

\section{Sea-ice extent}

Sea-ice extent, defined as the area of ocean covered by at least 10 to $15 \%$ of sea ice, is the most widely used parameter describing sea-ice coverage. Before the advent of satellite imaging in the $1960 \mathrm{~s}$, information on ice extent was very limited, particularly in the Antarctic, and complete spatial and temporal coverage did not begin until the launch of the first passive microwave imager known as the electrically scanning microwave radiometer (ESMR) on the Nimbus-5 satellite in December 1972 (see, for example, Gloersen and others 1974, Zwally and Gloersen 1977).

The longest data set on monthly sea-ice cover with nearly-complete coverage of the Arctic from 1953 
to 1977, was compiled by Walsh and Johnson (1979) in order to examine the relationship between atmospheric variability and sea-ice variability; statistically significant correlations between the dominant modes in the atmosphere and in the sea ice were determined. In the Antarctic, characteristics of the seasonal cycle, including regional contrasts and interannual variations, were examined in detail using a four-year (1973-76) ESMR data set (Zwally and others 1983[a]). The most notable regional difference in the Antarctic is the more rapid growth of the ice extent to a near maximum in the Ross Sea sector $\left(160^{\circ} \mathrm{E}\right.$ to $130^{\circ} \mathrm{W}$ ) between March and July, in contrast to a slower growth to a maximum in the other regions in September. In all regions of the Antarctic, the seasonal decay is very rapid from October to January. The asymmetry in the Antarctic cycle, caused by the faster decay in spring and summer than the growth in fall and winter, is in contrast to a nearly symmetrical seasonal cycle in the Arctic around a March maximum and a September minimum (Walsh and Johnson (1979) noted that the Arctic growth rate is slightly more rapid than the decay).

The seasonal cycle of sea ice in the Southern Ocean for ten years (1973-82), shown in Figure 1

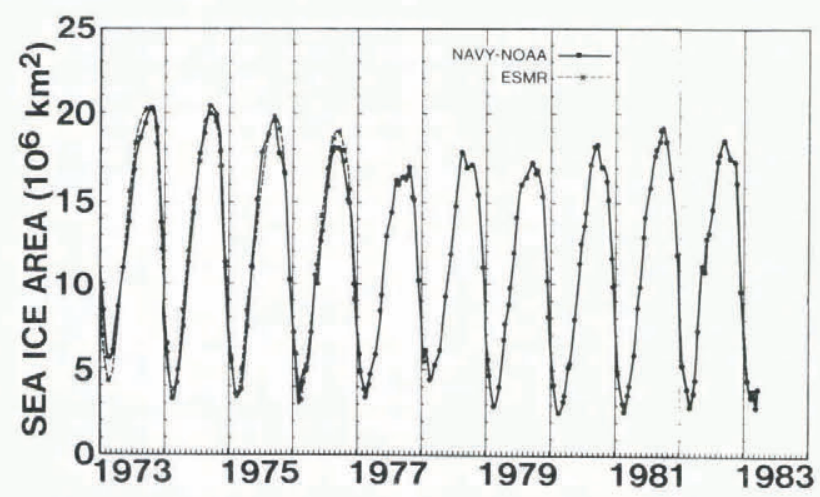

Fig.1. Seasonal cycle of Antarctic sea-ice extent. Areas (1) from US Navy-NOAA sea-ice maps 1973-81 and (2) from Nimbus-5 ESMR 1973-76 (adapted from Zwally and others $1983[\mathrm{c}])$.

which is adapted from Zwally and others (1983[c]), exhibits an interesting and unexplained variability. Over periods of three to five years ice extents with greater winter maxima are associated with ice extents with lesser summer minima (Fig.1). However, over the full nine-year period, the trends exhibited by linearfits to the data are nearly the same in each of the four seasons (Zwally and others 1983[c]). Regional interannual variability is large, with sea ice decreasing in some regions while increasing in others. A significant decrease in overall annual mean ice extent on the Southern Ocean during the mid-1970s, suggested by Kukla and Gavin (1981) to be reflecting a $\mathrm{CO}_{2}$-induced warming, has not been maintained. In particular, ice extent in the Weddell Sea sector $\left(60^{\circ} \mathrm{W}\right.$ to $\left.20^{\circ} \mathrm{E}\right)$ has rebounded after a large decrease concurrent with a major oceanographic anomaly, i.e. the Weddell polynya. A decrease of similar magnitude in the Ross Sea sector followed the Weddell decrease by three years with a minimum in 1980 . The mid-1970s decrease was also preceded by an increase in ice extent from 1966 to 1972, again indicating the presence of short-term components of variation that obscure any long-term trends that might be caused by a $\mathrm{CO}_{2}$ warming.

Modeling of the seasonal cycle over several years by Parkinson and Bindschadler (1984, in press) has provided estimates of the sensitivity of the amplitude of the Antarctic seasonal cycle to changes in atmospheric temperature. The aforementioned modulation of the seasonal cycle, shown by the association of greater winter maxima with lesser summer minima and conversely, presents a challenging problem for simulation by models. The amplitude modulations (of $30 \%$ ) occurred in several individual sectors, but with an apparent phase shift of about 2 to 3 a successively from the Weddell, to the Ross, and to the Bellingshausen-Amundsen seas sector $\left(130^{\circ} \mathrm{W}\right.$ to $\left.60^{\circ} \mathrm{W}\right)$. Since it is unlikely that the cause of this modulation is limited to the sea-ice system, models that account for relevant oceanic and atmospheric interactions will probably be required to simulate and explain the observed interannual variations. Sea-ice concentration

Sea-ice concentration, i:e., the percentage of a given ocean area covered by sea ice, has been derived from the ESMR data for the Southern Ocean to an estimated accuracy of $15 \%$ at each location (Comiso and Zwally 1982). The actual ice area is obtained by spatial integration of the concentration. The open water with in the ice pack is the difference between the ice extent and the actual ice area, and the mean ice concentration is the actual ice area divided by the total ice extent. Any two of 'these four parameters are sufficient to describe the area of ice coverage and $i$ ts compactness.

In the Antarctic, the seasonal cycle of open water clearly differs from the seasonal cycles of ice extent and actual ice area, as shown in Figure 2.

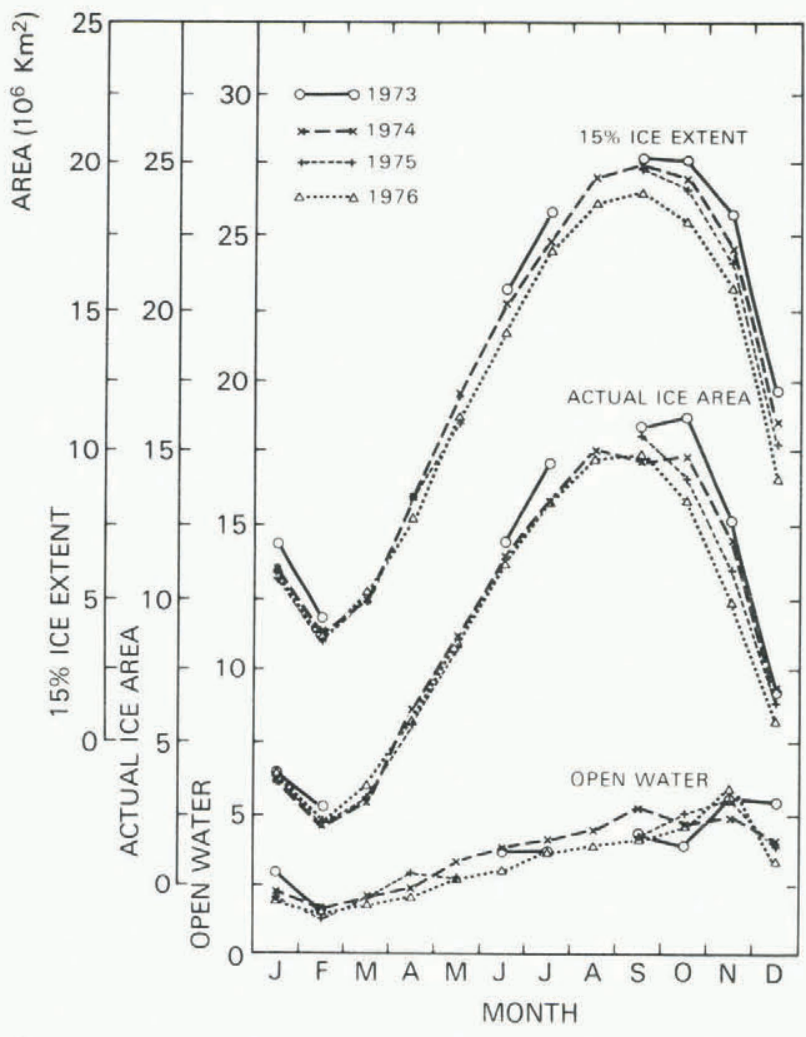

Fig.2. Interannual variation of the seasonal cycle of $15 \%$ extent, the actual ice area, and the open water with in the pack for the total Southern Ocean (from Zwally and others 1983[a]).

Typically, the area of open water increases linearly for about nine months from February to November and then decreases sharply, although there is considerable monthly variation about the mean behavior. During the growth season, the total open-water area with in the ice pack naturally increases as the increase in total ice extent expands the region in which open water can occur. The amount of open water is also related to the mean ice concentration, which reflects the rates 
of ice divergence and refreezing with in the ice pack and the resulting areas of open leads and polynyas. The area of open water continues to increase for one to two months after the time of maximum ice extent, a feature which is also shown by the faster decrease in the actual ice area than in the ice extent just after their maxima (Fig.2). This continued increase of open water during the early part of the decay season is consistent with a rapid early decrease in areas of highly concentrated ice and a corresponding decrease in mean concentration (Zwally and others 1983[a]).

The mean ice concentration in the Southern 0cean ranges from approximately 60 to $80 \%$ in summer and winter, respectively. Although the summer ESMR values are in good agreement with the Navy-National Oceanic and Atmospheric Association (NOAA) seaice maps (Godin and Barnett 1979) and reported, for example, by Kukla and Gavin (1981), the Navy-NOAA maps show less than $5 \%$ open water in winter in contrast to the $20 \%$ values derived from ESMR data. The ESMR-derived concentrations are considered to be more accurate (e.g. Comiso and Zwally 1982, and Zwally and others 1983[a]), because the microwave techniques account for all the open water in leads and polynyas, no matter how small the individual areas of open water are. From February to March, the Navy-NOAA estimates of mean ice concentration increase abruptly from 70 to approximately $95 \%$ and in April to $99 \%$; these values would be typical of the highly constrained winter ice in the central Arctic Ocean. The ESMR-derived values show a much smoother increase in mean concentration throughout the growth season as the ice cover expands toward the equator. In the Southern Ocean, the unconstrained ice is much more divergent than in the Arctic Ocean, producing large areas of reduced ice concentration, particularly near the ice edge as shown by ESMR. With in the center of the ice pack, much of the ice cover has concentrations with in the range of 88 to $100 \%$ ( $12 \%$ to zero open water). Near the Antarctic coast, reduced concentrations are also observed, due to the opening and closing of near-shore leads and polynyas.

Over the four years (1973-76), the trends in ice extent and actual ice area are very similar in the Antarctic, but differences of short duration are probably the result of differences in synoptic weather patterns. An example of different variability in ice extent, compared to actual ice area, is given by the winter ice covers of 1973 and 1974, for which the year-to-year decrease in actual ice area was greater than the decrease in ice extent (Fig.2). During July, September, and October 1973, less open water occurred within the ice pack than in 1974. The existence of a greater ice extent and a lesser amount of open water suggests that the ice pack was generally less divergent during the winter of 1973. Since there is the possibility of longer-term trends in the differences between ice extent and actual ice area due, for example, to variations in atmospheric circulation or storm frequency, longer-term observation and analys is of both actual ice area and ice extent are needed to describe and understand the observed changes in the sea-ice cover.

The sea-ice concentrations shown in Figure 3 are derived (Cavalieri and others 1981 and in press) from the multifrequency and dual-polarization passive microwave imager termed the scanning multichannel microwave radiometer (SMMR) on Nimbus-7 which was launched in October 1978. During winter months, the amount of open water with in the central Arctic ice pack may be only several percent, which is less than the amount generally indicated by the concentrations in Figure 3 (upper). The variation of ice emissivity with ice type, a characteristic which enables the mapping of multiyear ice as discussed below, also introduces errors in the determination of ice concentration. Additional research is required on the methods for extraction of ice parameters from multi- frequency data over regions having small percentages of open water and mixtures of ice types.

\section{Multiyear ice distribution}

The multiyear ice fraction is defined as the percentage of the ice cover consisting of ice that has survived at least one summer's melt season. This definition of multiyear ice is of ten used rather than the term "old ice", which, in WMO sea-ice terminology (World Meteorological Organization 1970), is defined to include second-year ice and "multiyear" ice as sub-categories, with "multiyear" defined as ice that is older than second-year. Due to brine drainage processes in the freeboard, Arctic multiyear ice has a structure that produces a lower microwave emissivity than first-year ice (see, for example, Wilheit and others 1972, Gloersen and others 1978). The lower microwave emissivity allows determination of the multiyear ice fraction (Fig.3 (lower)) from the multifrequency SMMR data (Cavalieri and others 1981 and in press). However, in the Weddell Sea region of Antarctica, where extensive brine drainage does not occur (Gow and others 1982), the multiyear ice is radiometrically similar to first-year ice and is not distinguished from first-year ice by passive microwave techniques (Zwally and others 1983[a]).

As more is learned about the microwave properties of multiyear ice, in particular, various distinctions of ice types, or clarifications of terminology appropriate to remote sensing, may be needed. For example, as discussed in Campbell and others (1983), refrozen melt ponds appear to have microwave emissivities similar to first-year ice. Consequently, the area of refrozen melt ponds on multiyear ice floes in the Arctic is probably classified by the passive microwave techniques as first-year ice, even though the substrata of the melt ponds is multiyear ice. Therefore, the present determination of the multiyear ice fraction, as shown in Figure 3 (lower), would be the fraction of the ice cover consisting of multiyear ice floes multiplied by the fraction of the multiyear ice floes not covered by melt ponds having the emissivity of first-year ice. Confirmation is needed of this interpretation, which provides an explanation of the discrepancy between the low values $(\sim 40 \%)$ of the multiyear ice fraction in the region several hundred kilometers from the edge of the multiyear ice pack and other higher estimates (N Untersteiner private communication). The largest values of the multiyear fraction $(>90 \%)$ indicated by the SMMR data are correctly located in the region of the known highest multiyear ice fraction, and lower coverage of melt ponds, north of the Canadian Arctic.

Interannual variability of the extent of the multiyear ice pack can be studied by observation of the extent of sea ice at the summer minimum (see, for example, Carsey 1982), or by observation of the multiyear ice fraction throughout the winter months. Changes in the actual area of multiyear ice during winter, due to ridging and other processes, should be small, but the distribution of multiyear ice can be expected to change due to overall drift of the pack and continual movement within the pack. Studies of the seasonal and interannual changes in the extent and distribution of multiyear ice should be possible with sequential data such as those displayed in Figure 3 (lower).

North of Alaska, in February 1979, a band of predominantly first-year ice several hundred kilometers wide extended from the Beaufort Sea to the East Siberian Sea (Fig.3). The edge of the pack around the time of the previous summer minimum (23-26 September 1978, shown on Fig.3 (lower)), shows that this band of first-year ice was consistent with the unusually large extent of open water there in the summer. Therefore, the SMMR data do in fact outline the approximate position of the multiyear pack in winter. Differences between the boundary at the summer minimum and the boundary of the multiyear pack 


\section{CONCENTRATION}
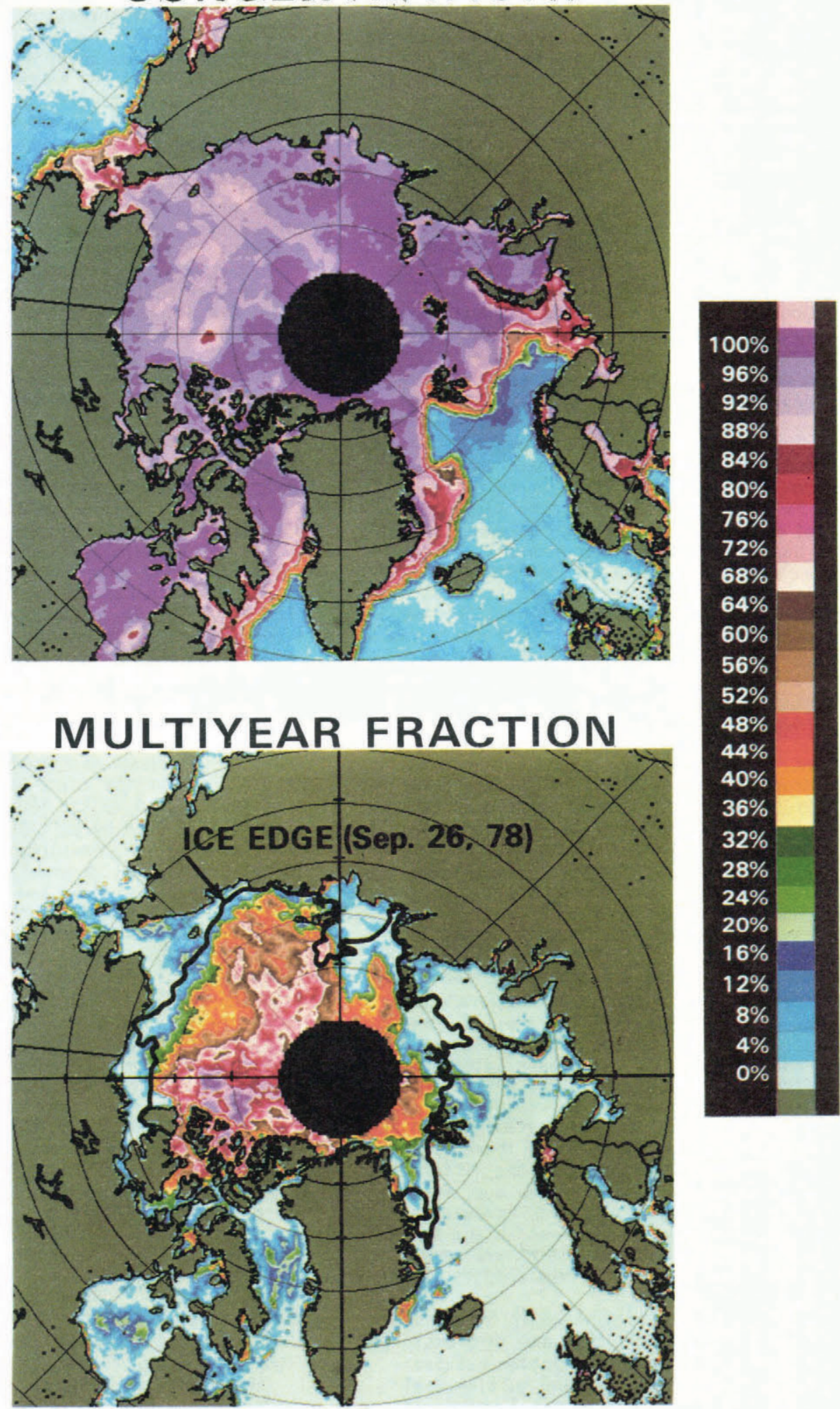

FEB 3-7, 1979

Fig.3. Upper: Arctic sea-ice concentration for 3-7 February 1979 from Nimbus-7 SMMR data. Lower: multiyear ice fraction from SMMR data for the same period. The ice edge at the approximate minimum extent of the previous summer from the US NavyNOAA map for 23-26 September 1978 is overlaid on the multiyear ice fraction. 
in February may be due in part to the influence of new ice growth on the ice edge near the summer minimum and in part to drift of the multiyear pack during winter.

In some regions during winter months the boundary of the multiyear ice pack can also be discerned in the single-wavelength ESMR data as a strong spatial gradient in the brightness temperature. In the Laptev and East Siberian seas during November this boundary is exhibited by a decrease in brightness temperature from $240 \mathrm{~K}$, over areas covered totally by first-year ice, to $225 \mathrm{~K}$ over multiyear ice, in a distance of about $100 \mathrm{~km}$ from one to the other. Analys is of the $232 \mathrm{~K}$ contour, the approximate midpoint of th is gradient, in the Laptev Sea around $130^{\circ} \mathrm{E}$ and $80^{\circ} \mathrm{N}$, for example, shows that the contour lies inside the position of the edge at summer minimum. From December 1973 to April 1974, the $232 \mathrm{~K}$ contour moved about $200 \mathrm{~km}$ northward, cons istent with a general movement of the ice pack with the transpolar drift stream. A similar displacement of the multiyear pack during the winter of 1978-79 is evident in Figure 3 (10wer). Preliminary analys is of the ESMR data for 1973-76 indicates that the drift of the $232 \mathrm{~K}$ contour during winter tends to be less in the East Siberian Sea than in the Laptev Sea, and the drift is quite variable from year to year. These preliminary results illustrate the potential for studies of the extent, distribution, and dispersion of the multiyear ice pack in the Arctic, its seasonal cycle, and its interannual variability, similar to studies of the total ice cover.

ICE-SHEET AND ICE-SHELF VARIABILITY

The surfaces of ice sheets and ice shelves are subject to the seasonal cycle of temperature, radiation, precipitation, and ablation, as well as longerterm variations of the atmosphere, ocean, and solar insolation. Most of the ice parameters of interest should be averaged over at least one year, consistent with the slow response of glaciers to changes in boundary conditions. One exception is the extent and duration of surface melting in summer, which requires daily observations for studies of interannual variations. Two important parameters which are best observed by satellite in the study of the long-term behavior of ice sheets and ice shelves are changes in surface elevation and in the position of ice-shelf fronts.

Surface elevation and ice margins

At present it is not known whether the existing ice sheets of Greenland and Antarctica are growing or shrinking. Present estimates of mass balance, which are based on estimates of the mass input (accumulation rate) and mass output (ablation, bottom melting, and iceberg discharge), are probably only accurate to $\pm 50 \%$. A review of results from the few areas which have been studied in detail by surface measurements

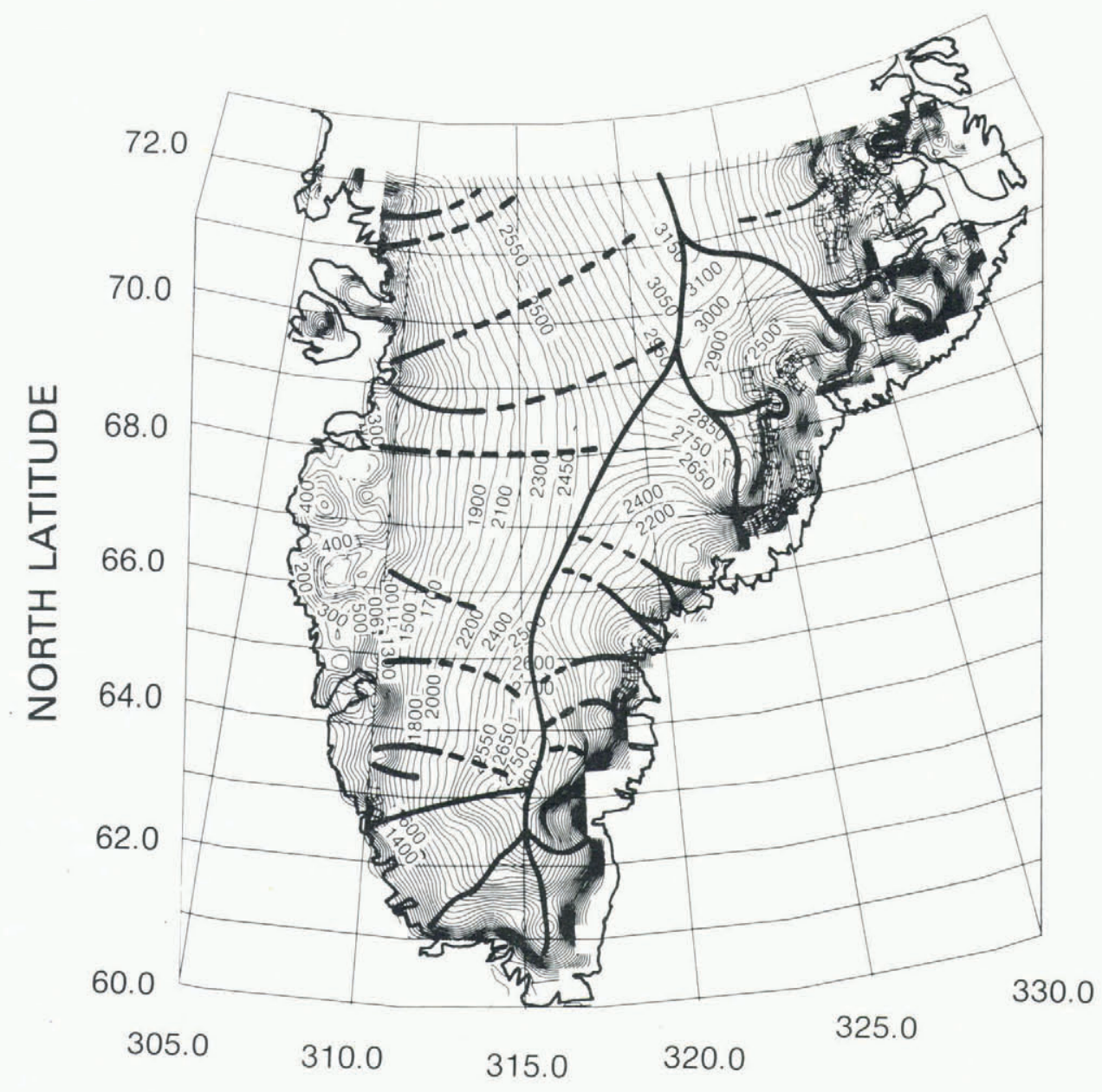

\section{EAST LONGITUDE}

Fig.4. Surface elevation contours of southèrn Greenland derived from Seasat radar altimetry. Delineation of major drainage basins, based on surface topography, by $R$ A Bindschadler. 
indicate that either thickening or thinning of the local ice is the rule rather than the exception and steady state appears to be rare (Zwally and others 1981).

Observation of land-based ice margins in isolation is known not to be a very useful indicator of ice-sheet behavior, because the response of the ice sheet margins to changes in other parts of the ice sheet is very slow. Therefore, on ice sheets, observation of the entire surface elevation is needed. In contrast, because ice shelves are floating, changes at the ice-shelf front are more rapidly coupled with other parts of the ice shelf. Compared to ice sheets, the response of ice shelves to climate change can be fast (Thomas and others 1979) with significant changes possible within a century. For several reasons, such as the controlling effect of ice shelves on ice-sheet discharge upstream, long-term observation of ice shelf behavior from space is especially important. Satellite laser altimetry (Zwally and others 1981, Bufton and others 1982) provides a potential method of determining net mass balance, and hence changes in ice volume, directly from repeated measurements of surface elevation. Mean elevation changes of about $10 \mathrm{~cm}$ over areas of 100 to $5000 \mathrm{~km}^{2}$ could be detected, allowing studies of regional and overall mass balance. Satellite radar altimetry, while less accurate than laser altimetry, has already been used for mapping the surface topography of portions of the Greenland and Antarctic ice sheets (Zwally and others $1983[\mathrm{~b}])$. The surface topography of southern Greenland, uncorrected for slope-induced errors (Brenner and others 1983), is shown in Figure 4 together with a preliminary delineation of the major drainage basins ( $R$ A Bindschadler private communication).

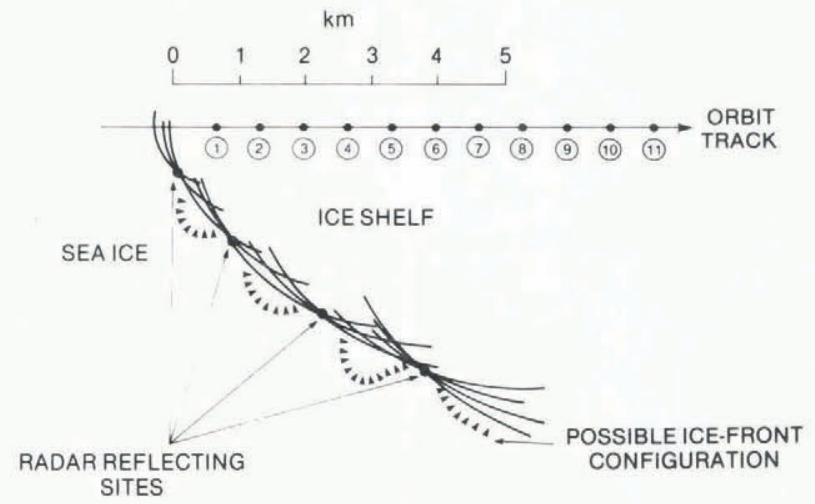

Fig.5. A portion of the Amery ice front derived from Seasat radar altimetry (from Thomas and others 1983).

Ultimately, repetitive satellite measurement of surface elevations along the major flow 1 ines will provide unique information for studies of the present state of ice flow. For example, by measuring changes in surface elevation it should be possible to determine whether the central portions of the ice sheets are in balance with the margins. Other information obtainable from accurate measurements of surface elevation includes the thickness of ice shelves and estimates of bottom melting rates.

Although changes in the position of ice-shelf fronts can be monitored by Landsat-type imagery with a spatial resolution of 30 to $100 \mathrm{~m}$, the absolute accuracy of geographical location is not so well determined. Recently, Thomas and others (1983) have shown that satellite radar altimetry can be used to map the seaward ice margins to an absolute horizontal accuracy of 100 to $1000 \mathrm{~m}$ (Fig.5). From continual observation by radar altimetry, the short-term variations of the ice front due to calving of major icebergs could be determined, and possibly secular changes in the position of the front also.
Surface cl imate parameters

Several parameters describing the surface climate of the ice sheets are potentially observable from space, such as the extent and duration of surface melting, accumulation rates (in the dry-firn zones), and surface temperature. Some of the progress on observing these parameters is described briefly.

The brightness temperature $T_{B}$ of snow increases. markedly with wetness (e.g. Stiles and Ulaby 1980) to values as high as $260 \mathrm{~K}$ at the ESMR wavelength of $1.55 \mathrm{~cm}$, corresponding to an emissivity of $0.95 \mathrm{at}$ the melting point. The magnitude of the change in $T_{B}$ due to surface melting depends on the value of $T_{B}$ of the dry firn, which ranges form 145 to $220 \mathrm{~K}$. In regions of significant summer melting, such as the Larsen Ice Shelf in Antarctica and the percolation zone of southwest Greenland, $T_{B}$ values for dry firn are about $160 \mathrm{~K}$, corresponding to an emissivity of about 0.7 (e.g. Zwally and Gloersen 1977). The $T_{B}$ of dry firn also varies with the seasonal temperature cycle, but with a smaller amplitude than that of the surface temperature because the emissivity is less than unity, and also the radiation emanates from below the surface where the seasonal temperature fluctuations are damped (Zwally 1977, Comiso and others 1982). The rise in T $B$ due to the onset of surface wetness is therefore relatively large and easy to detect. Examples of increases in $T_{B}$ from about $160 \mathrm{~K}$ for dry firn to $245 \mathrm{~K}$ for wet firn on ice shelves of the Antarctic peninsula are shown in Zwally and Gloersen (1977). Somewhat smaller increases of $T_{B}$ with wetness on the percolation zone of Greenland are shown in Figure 6. Mapping of the

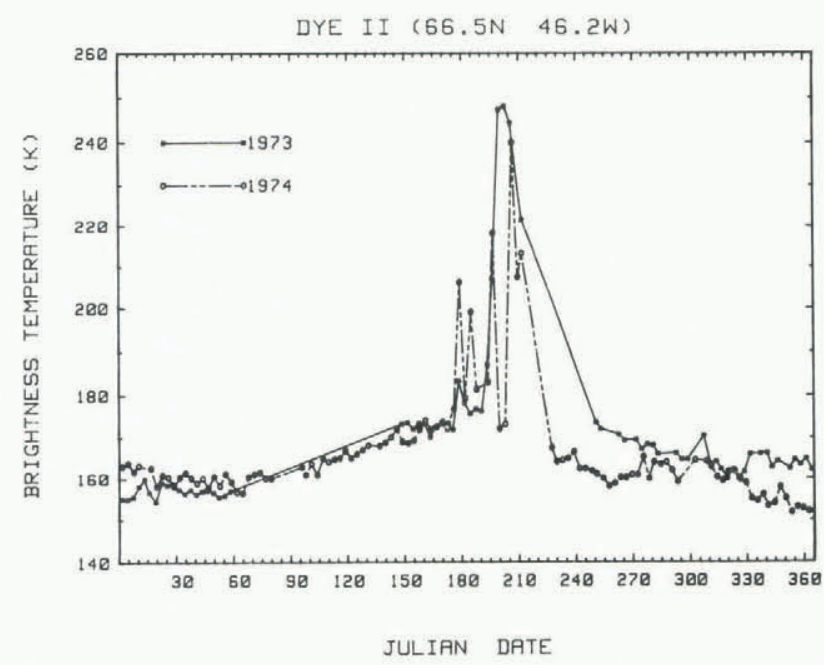

Fig.6. Microwave brightness temperature at Dye II station on the percolation zone of southern Greenland showing marked increase during period of summer melting.

extent and duration of summer melting will require systematic analys is of passive microwave data to delineate the times and regions where $T_{B}$ departs significantly from the smooth seasonal cycle typical of continuously dry firn.

The relationship between accumulation rates and microwave emissivity has been investigated (e.g. Chang and others 1976, Zwally 1977) showing that the microwave emission is sensitive to the grain size distribution with depth. An empirical relationship based on those studies was used by Rotman and others (1982) to make ice-sheet accumulation maps. Although the microwave methods are promising, additional research is needed because factors other than the accumulation rate (such as the temperature $h$ istory of the firn) affect the grain-size distribution with depth.

An independent measurement of the physical temperature would greatly assist the mapping of accumulation 
rates from the microwave measurements, as well as being of direct interest to studies of ice-sheet climate. Thermal infrared measurements from a satellite have been used recently (Comiso 1983) for measurement of sea-ice surface temperatures, but substantial difficulties are encountered in eliminating the effects of clouds in the intervening atmosphere. Further developments with microwave and infrared methods should lead to useful mapping of accumulation rates and surface temperatures of the ice sheets.

\section{SUMMARY}

Significant progress has been made in the development of methods for observing the variability of polar ice, especially the seasonal cycle of seaice extent. In particular, the interannual variability of the Antarctic sea ice has been shown to exhibit regional and seasonal characteristics over periods of three to five years that differ significantly when compared to decadal time scales. The extent, drift, and dispersion of the multiyear ice pack can be derived from new satellite data. Observation of icesheet elevations and the positions of ice-shelf fronts by satellite altimetry has been initiated and should lead to a determination of the long-term behavior of the ice.

The importance of continual synoptic observations of polar ice is illustrated by the large regional and interannual variability of sea ice obtained from space observations, and by the characteristic regional behavior of ice sheets and ice shelves as suggested by field studies. In some cases, additional development in order to measure particular parameters is needed, and in others the principal need is for the systematic processing and analysis of existing satellite data. In general, however, the continued acquisition of satellite data on polar ice cannot be assumed. New sensors such as laser altimeters are needed to measure certain parameters, and for others continued operation of proven sensors, such as passive microwave imagers, is required on polar orbiting satellites.

\section{ACK NOWLEDGEMENTS}

This research was supported by NASA's Oceans Program. I thank Dr Don Cavalieri for the SMMR image used in Figure 3.

\section{REFERENCES}

Brenner A C, Bindschadler R A, Thomas R H, Zwally H J 1983 Slope-induced errors in radar altimetry over continental ice sheets. Joumal of Geophysical Research 88(C3): 1617-1623

Bufton $\mathrm{J}$ L, Robinson J E, Femiano M D, Flatow F 1982 Satellite laser altimeter for measurement of ice sheet topography. IEEE Transactions. Geoscience and Remote Sensing GE-20: 544-549

Campbell W J, Gloersen P, Zwally H J 1983 Aspects of Arctic sea ice observable by sequential passive microwave observations from the Nimbus -5 satellite. In Dyer I, Chryssostomidis C (eds) Aretic technology and policy. Washington, etc, Hemisphere Publishing Corporation: 197-222

Carsey F D 1982 Arctic sea ice distribution at end of summer 1973-1976 from satellite microwave data. Joumal of Geophybical Research 87(C8): 5809-5835

Cavalieri D J, Gloersen P, Campbell W J 1981 Observations of sea ice properties with the Nimbus-5 SMMR. In IEEE intemational geoscience and remote sensing symposium (IGARSS'81). Proceedings Vol 1. New York, Institute of Electrical and Electronic Engineers: 69-78

Cavalieri D J, Gloersen P, Campbell W J In press Determination of sea ice parameters with the Nimbus7 SMMR. Jourmal of Geophysical Research

Chang $T C$, Gloersen $P$, Schmugge $T$, Wilheit $T T$, Zwally H J 1976 Microwave emission from snow and glacier ice. Joumal of Glaciology 16(74): 23-39
Comiso J C 1983 Sea ice effective microwave emissivities from satellite passive microwave and infrared observations. Joumal of Geophysical Research 88(C12): 7686-7704

Comiso J C, Zwally H J 1982 Antarctic sea ice concentrations inferred from Nimbus -5 ESMR and Landsat imagery. Jourmal of Geophysical Research 87(C8): 5836-5844

Comiso J C, Zwally H J, Saba J L 1982 Radiative transfer modeling of microwave emission and dependence on firn properties. Annals of Glaciology 3: $54-58$

Coon M D 1980 A review of AIDJEX modeling. Inter national Association of Hydrological Sciences Publication 124 (Symposium of Seattle 1977 - Sea Ice Processes and Models): 12-27

Dewey K F, Heim R 1982 A digital archive of northern hemisphere snow cover November 1966 through December 1980. Bulletin of the American MeteoroZogical Society 63(10): 1132-1141

Gloersen $P$, Wilheit T T, Chang T C, Nordberg W, Campbell WJ 1974 Microwave maps of the polar ice of the Earth. Bulletin of the American Meteorological Society 55(12): 1442-1448

Gloersen P, Zwally H J, Chang A T C, Hall D K, Campbell W J, Ramseier R 01978 Time-dependence of sea-ice concentration and multiyear ice fraction in the Arctic basin. Boundary-Layer Meteorology 13(1-4): 339-359

Godin R H, Barnett D G 1979 Global sea ice limits. Glaciological Data Report GD-7: 25-36

Gow A J, Ackley S F, Weeks W F, Govon i J W 1982 Physical and structural characteristics of Antarctic sea ice. Annals of Glaciology 3: 113-117

Hibler W D III, Ackley S F 1982 On modeling the Weddell Sea pack ice. Annals of Glaciology 3: $125-130$

Kukla G, Gavin J 1981 Summer ice and carbon dioxide. Science 214(4520): 497-503

Kunzi K F, Patil S, Rott H 1982 Snow-cover parameters retrieved from Nimbus-7 scanning multichannel microwave radiometer (SMMR) data. IEEE Transactions on Geoscience and Remote Sensing GE-20 (4): $452-467$

Matson M, Wiesnet D R 1981 New data base for climate studies. Nature 289(5797): 451-456

Parkinson C L, Bindschadler R A 1984 Southern Ocean sea-ice response to atmospheric warming (Abstract). Annals of Glaciology 5: 222

Parkinson $\mathrm{C} L$, Bindschadler $\mathrm{R} A$ In press Southern Ocean sea ice response to atmospheric warming. In Hansen J, Takahashi T (eds) Climate processes: sensitivity to solar irradiance and $\mathrm{CO}_{2}$. Washington, DC, American Geophysical Union (M Ewing Series 4)

Parkinson C L, Washington W M 1979 A large-scale numerical model of sea ice. Joumal of Geophysical Research 84(C1): 311-337

Rotman S R, Fisher A D, Stael in D H 1982 Inversion for physical characteristics of snow using passive radiometric observations. Joumal of Glaciology 28(98): 179-185

Stiles W H, Ulaby F T 1980 The active and passive inicrowave response to snow parameters. 1. Wetness. Joumal of Geophysical Research 85(C2): 1037-1044

Thomas R H, Sanderson T J O, Rose K E 1979 Effect of climatic warming on the West Antarctic ice sheet. Nature 277(5695): 355-358

Thomas R H, Martin T V, Zwally H J 1983 Mapping icesheet margins from radar-altimetry data. Annals of Glaciology 4: 283-288

Walsh J E, Johnson C M 1979 An analys is of Arctic sea ice fluctuations, 1953-77. Journal of Physical oceanography $9(3)$ : $580-591$

Wilheit T T, Nordberg W, Blinn J C, Campbell W J, Edgerton A T 1972 Aircraft measurements of microwave emission from Arctic sea ice. Remote Sensing of Environment 2(3): 129-139 
World Meteorological Organization 1970 WMO sea-ice nomenclature; terminology, codes, and illustrated glossary. Geneva, Secretariat of the World Meteorological Organization (WMO/OMM/BMO 259, TP 145)

Zwally H J 1977 Microwave emissivity and accumulation rate of polar firn. Joumal of Glaciology 18 (79): $195-215$

Zwally H J, Gloersen P 1977 Passive microwave images of the polar regions and research applications. Polar Record 18(116): 431-450

Zwally H J, Thomas R H, Bindschadler R A 1981 Icesheet dynamics by satellite laser altimetry. In IEEE intemational geoscience and remote sensing symposium (IGARSS'81). Proceedings Vol 2. New York, Institute of Electrical and Electronics Engineers: 1012-1022 [A1so NASA Technical Memorandrom 82128]

Zwally H J, Comiso J C, Parkinson C L, Campbel1 W J, Carsey F D, Gloersen P 1983[a] Antarctic sea ice, 1973-1976: satellite passive microwave observations. NASA Special Publication SP-459

Zwally $\mathrm{H} \mathrm{J}$, Bindschadler R A, Brenner A C, Martin T V, Thomas RH 1983[b] Surface elevation contours of Greenland and Antarctic ice sheets. Joumal of Geophysical Research 88(C3): 1589-1596

Zwally H J, Parkinson C L, Comiso J C 1983[c] Variability of Antarctic sea ice and changes in carbon dioxide. Science 220(4601): 1005-1012 